\title{
Intersimple Sequence Repeat Markers for Fingerprinting and Determining Genetic Relationships of Walnut (Juglans regia) Cultivars
}

\author{
Daniel Potter, Fangyou Gao, Giovanna Aiello, Charles Leslie, and Gale McGranahan \\ Department of Pomology, 1045 Wickson Hall, University of California, One Shields Avenue, Davis, CA 95616
}

AdDitional INDEX WORDS. cultivar identification, molecular markers, Juglandaceae

\begin{abstract}
AвSTRaCt. The utility of intersimple sequence repeat (ISSR) markers for identification of English or Persian walnut (Juglans regia L.) cultivars was explored. Four cultivars were screened with 47 ISSR primers; eight of these primers, which generated reproducible and informative data, were selected for further study. Two individuals from each of 48 cultivars, including many currently important in the California walnut industry as well as accessions from Europe and Asia, were then examined with the eight ISSR primers. Polymerase chain reaction (PCR) products were separated on agarose gels and stained with ethidium bromide. Fifty-four bands were scored as present or absent in each cultivar; of these, 31 (57\%) were polymorphic among the 48 cultivars. Combined data from the eight ISSR primers provided a unique fingerprint for each of the cultivars tested. Fifteen of the cultivars could be distinguished from all others with just one primer, 31 with a minimum of two primers, and two required three primers. Pairwise genetic distances between the cultivars were calculated and a dendrogram was generated using the neighbor-joining algorithm. Some of the groupings in the dendrogram corresponded to groups which, based on known pedigrees, are genealogically closely related. Others included accessions from diverse genetic and/or geographic origins. These results can be attributed to a combination of the limitations of the ISSR method for inferring genetic relationships, on the one hand, and the complex history of walnut cultivar development involving extensive exchange and breeding of germplasm from different geographic regions, on the other.
\end{abstract}

Juglans regia (Juglandaceae), the English or Persian walnut, is the most economically important member of the genus Juglans L. The species is cultivated for edible nuts throughout the temperate regions of the world. In the United States, 99\% of the walnut crop is produced in California, where the crop has been grown since the $18^{\text {th }}$ century when plants from South America were grown around early Spanish missions (Beede and Hasey, 1998; Nicese et al., 1998). The modern California walnut industry is considered to have been started in the late $19^{\text {th }}$ century by two men: Joseph Sexton, who planted nuts believed to have originated in either Chile or China at his ranch in southern California, and Felix Gillet, who imported several walnut cultivars from France to northern California (Beede and Hasey, 1998; Tulecke and McGranahan, 1994). The walnut breeding program at the University of California, Davis, was begun in 1948. Since then, introductions from Europe and Asia have been used in the development of new cultivars in California (Forde and McGranahan, 1996; see Fig. 1). Thus, many of the walnut cultivars currently grown in California contain genetic contributions from cultivars from diverse geographic regions.

Several previous studies have examined the genetic diversity of walnut cultivars using molecular markers. Such studies are useful for understanding the origins and relationships of germplasm and for providing genetic fingerprints that can be used to test or confirm the identity of plant materials. Marker systems that have been used in previous studies of J. regia cultivars include isozymes (Arulsekar et al., 1986; Solar et al., 1993, 1994), restriction fragment-length polymorphism (RFLP) markers (Fjellstrom et

Received for publication 16 Mar. 2001. Accepted for publication 28 Aug. 2001 We thank Millie Lee and Teri Nguyen for technical assistance, and S. Arulsekar, Frank Blazich, Esteban Bortiri, Craig Chandler, and two anonymous reviewers for providing helpful comments on the manuscript. Financial support from the Walnut Marketing Board is gratefully acknowledged. The cost of publishing this paper was defrayed in part by the payment of page charges. Under postal regulations, this paper therefore must be hereby marked advertisement solely to indicate this fact. al., 1994), and randomly amplified polymorphic DNA (RAPD) markers (Nicese et al., 1998).

Development of molecular markers for characterization of walnut germplasm is essential to many aspects of walnut research and industry (Simon and Potter, 2001), including accurate identification of nursery stock and verification of paternity in breeding programs. The need for these markers in J. regia, especially as a reliable method of cultivar identification, is considered sufficiently important by the industry that the Walnut Marketing Board and the California Department of Food and Agriculture recently provided matching funds to support a multiyear project aimed at the development of simple sequence repeat (SSR), or microsatellite, markers for this crop.

The utility of various molecular marker systems for fingerprinting cultivars and studying genetic relationships has received a great deal of attention over the last decade. Microsatellite analysis is generally considered the most powerful method for a number of reasons, including maximum precision and reproducibility, but development of SSR markers requires considerable investment of time and money. Thus, many studies have employed faster, less expensive methods such as RAPD markers.

Intersimple sequence repeat (ISSR) markers (Zietkiewicz et al., 1994), like RAPD markers, are a quick, relatively inexpensive method for analyzing variability and developing genetic fingerprints in closely related biological materials. The ISSR method, which involves polymerase chain reaction (PCR) amplification of regions between SSR markers in the genome, has been considered a more reliable method than RAPD markers due to higher reproducibility (Moreno et al., 1998). The ISSR method may also generate greater polymorphism than RAPD markers, rendering it more suitable for comparisons of closely related genotypes (Moreno et al., 1998; Nagaoka and Ogihara, 1997). ISSR markers have been used in studies of cultivars in a number of horticultural crop plant taxa, including species of Citrus L. (Fang et al., 1997, 1998), Vitis L. (Moreno et al., 1998), and Prunus L. (Goulão et al., 2001). Thus, the goal of this study was to test the utility of ISSR 
markers for fingerprinting and studying genetic relationships among cultivars of J. regia, and to compare the results with those based on other molecular markers.

\section{Materials and Methods}

Plant material and dna extraction. Forty-eight $J$. regia cultivars were collected in Wolfskill Experimental Orchard, Winters, Calif. (Table 1). For each cultivar, two individuals were tested. Young leaves collected in Spring, 1999 were washed and frozen at $-80{ }^{\circ} \mathrm{C}$ until DNA extraction. Leaves were ground in liquid nitrogen and DNA was extracted by standard CTAB method (Doyle and Doyle, 1987). For two samples (one individual each of 'Howard' and 'Manregian'), buds were collected in Winter, 1999; the DNA extractions from those two samples were based on the method described by Lin and Walker (1998).

Primers. Initially, 47 ISSR primers (obtained from Genosys Biotechnologies, The Woodlands, Texas) were screened with four randomly selected cultivars to determine useful primers and possible polymorphisms. Eight ISSR primers that produced clearly scorable, polymorphic (present or absent), and reproducible DNA fragments were selected for use in this study (Table 2).

PCR AMPLIFICATION AND ELECTROPHORESIS. PCR amplifications were carried out in reaction volumes of $20 \mathrm{~mL}$, containing $1.0 \mathrm{~mL}$ of genomic DNA (50 ng), $2.0 \mathrm{~mL}$ of 10× buffer (Applied Biosystems, Foster City, Calif.), $1.5 \mathrm{~mL}$ of primer $\left(10 \mathrm{pmol} \cdot \mathrm{mL}^{-1}\right), 1.6 \mathrm{~mL}$

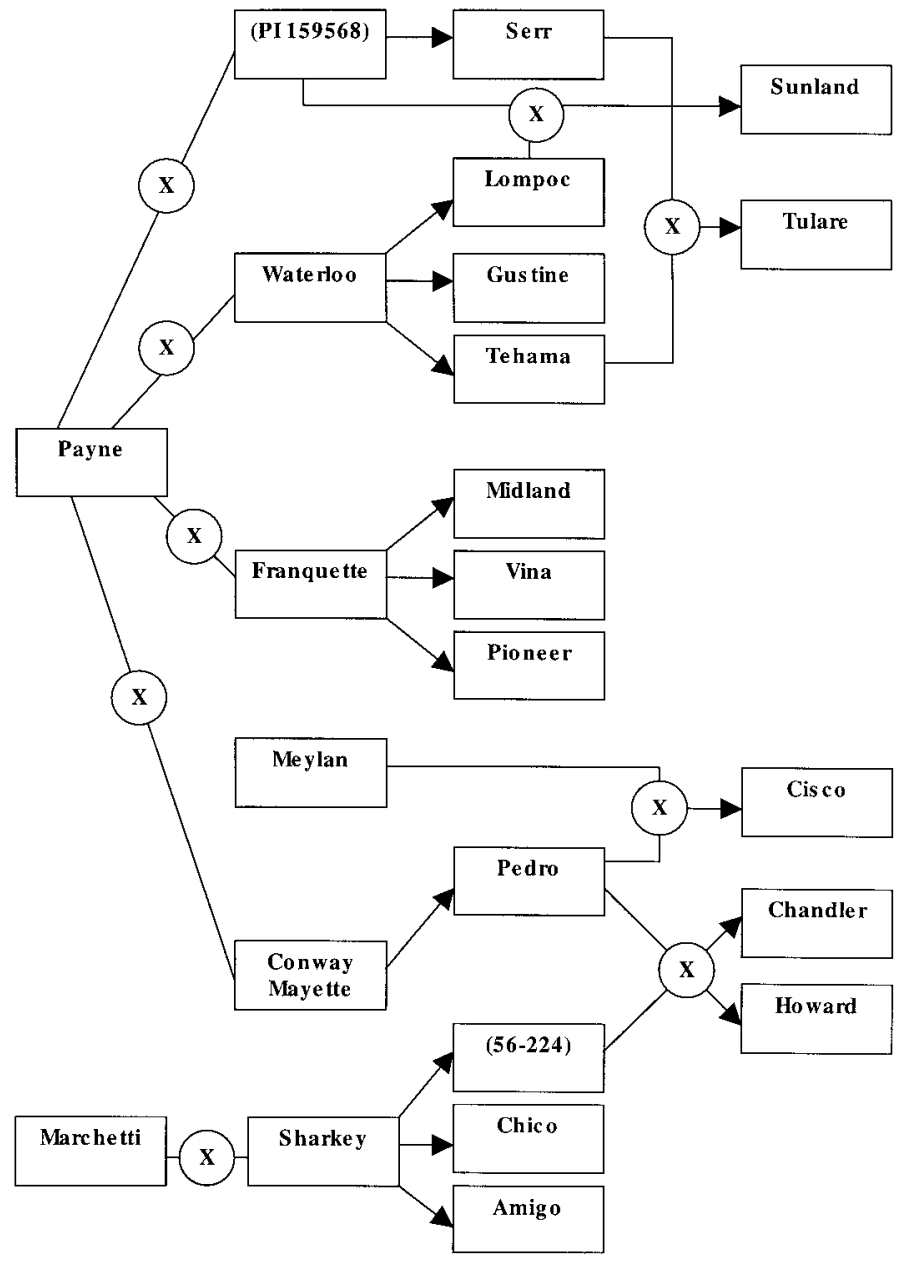

Fig. 1. Pedigree of some of the Juglans regia cultivars, redrawn from Tulecke and McGranahan (1994). Cultivars in parentheses were not included in this study. of dNTPs (2.5 mM of each), $1.8 \mathrm{~mL}$ of $\mathrm{MgCl}_{2}(25 \mathrm{~mm})$ and 0.12 $\mathrm{mL}$ ( 5 units $/ \mathrm{mL}$ ) of AmpliTaq Gold DNA polymerase (Applied Biosystems). Amplifications were performed in an Applied Biosystems GeneAmp PCR System 9600 Thermal Cycler under the following conditions: $95^{\circ} \mathrm{C}$ for $10 \mathrm{~min}$, followed by 35 cycles of denaturing at $94{ }^{\circ} \mathrm{C}$ for $30 \mathrm{~s}$; annealing at $50{ }^{\circ} \mathrm{C}$ for $1 \mathrm{~min}$; extension at $72{ }^{\circ} \mathrm{C}$ for $2 \mathrm{~min}$; and a final extension cycle at $72{ }^{\circ} \mathrm{C}$ for $7 \mathrm{~min}$. Six microliters of each PCR product was mixed with 4 $\mathrm{mL}$ loading buffer and electrophoresed on $2 \%$ (w/v) agaroseSynergel (Diversified Biotech, Boston, Mass.) in 0.5× TBE at $4 \mathrm{~V} \cdot \mathrm{cm}^{-1}$ for $4 \mathrm{~h}$. Gels were stained with ethidium bromide and photographed under ultraviolet light. The size of PCR products was estimated by comparison with a 100-base pair (bp) DNA ladder (Promega, Madison, Wis.). Reproducibility of the markers was confirmed by duplicate PCR reactions with one to several accessions using the same primer. Only primers that gave consistently reproducible patterns were used.

DATA ANALYSIS. ISSR bands were scored from photographs of the gels and binary coded as 1 or 0 for their presence or absence independently by two researchers to create a data matrix. In one case, a product was equivocal and a ? (missing data) was coded for the band in question. Only bands between 200 to $1700 \mathrm{bp}$ in length were scored; bands beyond this range were faint and omitted.

Pairwise genetic distances between cultivars were calculated in PAUP* version $4.0 \mathrm{~b} 8$ (Swofford, 2001), using the mean character difference option. A dendrogram based on those values was constructed using the neighbor-joining algorithm as implemented in PAUP* (Swofford, 2001).

\section{Results and Discussion}

QUALITY OF DATA. PCR products from amplification reactions using $J$. regia template DNA and ISSR primers were clearly distinguished on $2 \%$ agarose-Synergel (Fig. 2). Of the 47 primers tested, 19 revealed some polymorphisms among the 48 cultivars examined; eight of these, which generated clear and reproducible results, were selected for our final analysis. In three different primer-template combinations, the pattern generated by a particular primer was not the same for both individuals of the same cultivar. In each of those cases, the DNA extract from one of the individuals was deemed to be of poor quality, based on inconsistent amplification in reactions with other primers, and was omitted. In all other cases, the two individuals of a single cultivar were identical for all bands scored.

Fingerprinting of Cultivars. Fifty-four bands were scored in the 48 cultivars tested. Thirty-one $(57 \%)$ of these bands were polymorphic. The number of bands per primer ranged from 5 to 9 (average, 6.8); the number of polymorphic bands per primer ranged from 1 to 7 (average, 3.9). In their study of RAPD variation among 19 walnut genotypes (including many, but not all, of the cultivars studied herein), Nicese et al. (1998) detected a total of 23 polymorphic bands using 18 primers, each of which generated 1 to 2 polymorphic fragments, and only about $25 \%$ of all primers tested yielded scorable polymorphisms. Thus, although the materials used were not identical, it is clear that ISSR markers detect more polymorphism than RAPD markers in this species. As with RAPD markers (Nicese et al., 1998), ISSR markers provided unique banding patterns, or genetic fingerprints, for each of the cultivars tested (Table 3), but discrimination among all the cultivars requires the use of multiple primers (but fewer for ISSR markers than for RAPD markers). 
In Table 3, the different banding patterns observed with each primer have been recoded as different letters, and, for each cultivar, the minimum number of primers required to provide a unique fingerprint is given. For example, for Primer ISSR7, six bands were scored (see Fig. 1) and the letter $\mathrm{C}$ refers to the pattern " +++++ +", which was observed only in the cultivar 'Chinese 85-8'. From Table 3 , it can be seen that 15 of the cultivars could be distinguished from all others included in this study using just one primer, 31 required two primers, and two ('Badajoz' and 'Pioneer') required three primers to provide a unique fingerprint.
RELATIONSHIPS AMONG CULTIVARS. Pairwise distances between cultivars ranged from 0.037 (between 'Placentia' and 'Westside') to 0.31 (between 'Trinta' and each of the following cultivars: 'Adams 10', 'Sharkey', 'Placentia', 'Westside', and 'Sinensis').

The dendrogram generated from the ISSR genetic distance data using the neighbor-joining algorithm (Fig. 3) is here shown as unrooted, since, among the cultivars included, there was no clear outgroup. The shortness of many of the branches uniting groups of cultivars, relative to those leading to individual cultivars, suggests that many of the relationships depicted are not

Table 1. List of Juglans regia cultivars used in this study; origin and parentage is based on information reported by Tulecke and McGranahan (1994).

\begin{tabular}{|c|c|c|}
\hline Cultivar & Origin & Parentage \\
\hline 'Scharsch Franquette' & California-France & \\
\hline 'Waterloo' & California & \\
\hline 'Rouge de la Donan' & Europe & \\
\hline 'Chinese 85-8' & China & \\
\hline 'Alsoszentivani' & Hungary & \\
\hline 'xxx Mayette' & France & \\
\hline 'Midland' & Univ. of California & 'Franquette' x 'Payne' \\
\hline 'Pioneer' & Univ. of California & 'Franquette' $x$ 'Payne' \\
\hline 'Badajoz' & Spain & \\
\hline 'Carmello' & California & \\
\hline 'Lozeronne' & France & \\
\hline 'Adams 10' & Oregon & Selected seedling from PI 18256 \\
\hline 'Laciniata 93-5' & France & \\
\hline 'Howard' & Univ. of California & 'Pedro' x'56-224' \\
\hline 'Manregian' & China & \\
\hline 'Payne' & California & \\
\hline 'Sunland' & Univ. of California & 'Lompoc' x PI 159568 \\
\hline 'Vina' & California & 'Franquette' x 'Payne' \\
\hline 'Ashley' & California & 'Payne'? \\
\hline 'Serr' & California & 'Payne' x PI 159568 \\
\hline 'Lompoc' & Univ. of California & 'Waterloo' x 'Payne' \\
\hline 'Sharkey' & China? & \\
\hline 'Chico' & California & 'Sharkey' x 'Marchetti' \\
\hline 'Tehama' & Univ. of California & 'Waterloo' x 'Payne' \\
\hline 'Eureka' & California & \\
\hline 'Gustine' & California & 'Waterloo' x 'Payne' \\
\hline 'Placentia' & California & \\
\hline 'Westside' & California & \\
\hline 'Sinensis \#5' & Japan & \\
\hline 'Marchetti' & California & \\
\hline 'Cisco' & California & 'Meylan' x 'Pedro' \\
\hline 'Chandler' & Univ. of California & 'Pedro' x '56-224' \\
\hline ‘Amigo' & California & 'Sharkey' x 'Marchetti' \\
\hline 'Hartley' & California & 'Franquette' x 'Mayette' \\
\hline 'Tulare' & California & 'Tehama' x 'Serr' \\
\hline 'Meylan' & France & \\
\hline 'Early Ehrhardt' & Southern California & \\
\hline 'Conway Mayette' & California-France & \\
\hline 'Pedro' & Univ. of California & 'Conway Mayette' x 'Payne' \\
\hline 'Purpurea 86-11' & Europe & \\
\hline 'Abbotbad' & Pakistan & \\
\hline 'Trinta' & California & 'Waterloo'? \\
\hline 'Idaho' & Idaho & \\
\hline 'Poe' & California & \\
\hline 'Weeper' & Napa Valley & \\
\hline 'Concha' & Chile & \\
\hline 'Cascade' & Washington & \\
\hline 'Franquette' & France & \\
\hline
\end{tabular}


Table 2. ISSR primers used in this study.

\begin{tabular}{ll}
\hline \hline Primer & Sequence \\
\hline ISSR7 & $(\mathrm{AG})_{8} \mathrm{YC}$ \\
ISSR47 & $(\mathrm{AG})_{8} \mathrm{Y}$ \\
ISSR21 & $(\mathrm{AG})_{8} \mathrm{YT}$ \\
ISSR22 & $\mathrm{HVH}(\mathrm{CA})_{7} \mathrm{~T}$ \\
ISSR9 & $(\mathrm{CT})_{9} \mathrm{RC}$ \\
ISSR43 & $(\mathrm{GT})_{8} \mathrm{YA}$ \\
ISSR16 & $(\mathrm{TCC})_{5} \mathrm{RY}$ \\
ISSR28 & $(\mathrm{AGAA})_{4} \mathrm{AG}$ \\
\hline
\end{tabular}

strongly supported by the data. This was also true of the dendrograms based on RAPD data presented by Nicese et al. (1998) and of many of the groups recovered from RFLP data by Fjellstrom et al. (1994). In addition, some of the relationships in Fig. 3 do not correspond to what is known about the genealogical histories and geographic origins of the cultivars. These patterns may be attributed, in part, to limitations of the ISSR method (see below), but they also reflect a history of cultivar development that has included extensive exchange and breeding of materials from different parts of the world. Nonetheless, some of the groupings in Fig. 3 can be explained based on what is known about the genealogy and/or geographic origins of the cultivars (Tulecke and McGranahan 1994; Table 1, Fig. 1).

'Payne' is a cultivar that has been involved in the genealogy of many California cultivars. A large cluster including 'Payne' and many of its descendants was recovered (lower left-hand portion of Fig. 3); it comprised two large subclusters. The first of these included 'Franquette', a cultivar that originated in France and was brought to California in the 1870 s by Gillet, 'Scharsch Franquette' (from one 'Franquette' tree in Glenn County, Calif.), the California cultivar 'Poe', the French cultivars 'Lozeronne' and 'Meylan', and several cultivars derived from crosses involving one of the aforementioned cultivars ('Cicso' from 'Meylan' x 'Pedro', 'Hartley' from 'Franquette' $x$ 'Mayette', 'Pioneer' and 'Vina' from 'Franquette' $x$ 'Payne'). 'Lompoc', from a cross between 'Waterloo' and 'Payne', was also placed in this group, though each of its siblings, 'Gustine' and 'Tehama', grouped with a different cluster of cultivars.

The second subcluster included 'Payne' itself, as well as several other cultivars derived from it, including 'Serr', 'Sunland', 'Tulare', and 'Pedro'. 'Ashley', suspected of being a bud sport or seedling of 'Payne', clusters most closely with that cultivar. The two were indistinguishable with RFLP data (Fjellstrom et al., 1994) and the differences observed with ISSR markers tend to support the seedling, rather than the bud sport, origin, but they could also be explained as somatic mutations or nonparental bands (see below). Finally, the inclusion of the 'Chinese 85-8' cultivar, and of 'Cascade', originally from Washington and said to be from a cross between Russian and Manchurian cultivars, in this large group, support the hypothesis (see Tulecke and McGranahan, 1994) that 'Payne' itself may have had Chinese material as one of its parents, a conclusion not supported by RFLP data (Fjellstrom et al., 1994).

The grouping of 'Trinta' with 'Waterloo' is consistent with the suggestion (Tulecke and McGranahan 1994) that the former cultivar was a chance seedling of the latter. Both of these originated in California;
'Purpurea 86-11', a European cultivar, also groups with them; this group clusters with the group including 'Gustine', one of the cultivars from the cross between 'Waterloo' and 'Payne', and its half-sib 'Midland', one of the cultivars from the cross between 'Franquette' and 'Payne'.

The group including 'Amigo', 'Howard', 'Chico', 'Chandler', and 'Marchetti' represents a genealogically related set of cultivars (Fig. 1). 'Marchetti' is a parent (with 'Sharkey') of 'Amigo' and 'Chico' and a grandparent of 'Chandler' and 'Howard'.

Some of the groups in Fig. 3 comprise cultivars from similar areas (e.g., California and France), while several others include cultivars from diverse geographic regions. Examples of the latter include the group comprised of 'Idaho', a cold-hardy Carpathian type, and 'Alsoszentivani', from Hungary, and the group comprised of 'Rouge de la Donan', from Europe, and 'Sinensis \#5', from Japan.

Many of the cultivars included herein were not analyzed using RAPD markers by Nicese et al. (1998), and we did not include a few that they did, limiting the degree to which comparisons can be made between the two studies. In general, however, the dendrograms (our Fig. 3 and their Fig. 3) were quite different in terms of the relationships depicted, with some exceptions, notably, the close relationships between 'Howard' and 'Chandler', and between 'Serr' and 'Sunland'. Similar comments apply to comparisons between our study and the RFLP analysis of Fjellstrom et al. (1994); groupings supported by that analysis and ours include the relationships between 'Payne' and 'Ashley' (noted above) and between 'Meylan' and 'Hartley'.

Fjellstrom et al. (1994) found that RFLP data separated walnut germplasm into two major groups, one including material from California and Europe, and another including material from

Fig. 2. Amplification products from 11 Juglans regia cultivars with primer ISSR7. The fragments were separated by electrophoresis using a $2 \%$ agarose-Synergel and stained with ethidium bromide. From left to right: $100 \mathrm{bp}$ ladder (Promega); lanes 1-2: 'Scharsch Franquette'; lanes 3-4: 'Waterloo'; lanes 5-6: 'Rouge de la Donan'; lanes 7-8: 'Chinese 85-8'; lanes 9-10: 'Alsoszentivani'; lanes 1112: 'xxx Mayette'; lanes 13-14: 'Midland'; lanes 15-16: 'Pioneer'; lanes 1718: 'Badajoz'; lanes 19-20: 'Carmello'; and lanes 21-22: 'Lozeronne'. Bands $\mathrm{A}, \mathrm{C}$, and D were present in all cultivars examined; band B was found only in 'Chinese 85-8'; and bands E and F were present in some, but not all, cultivars.

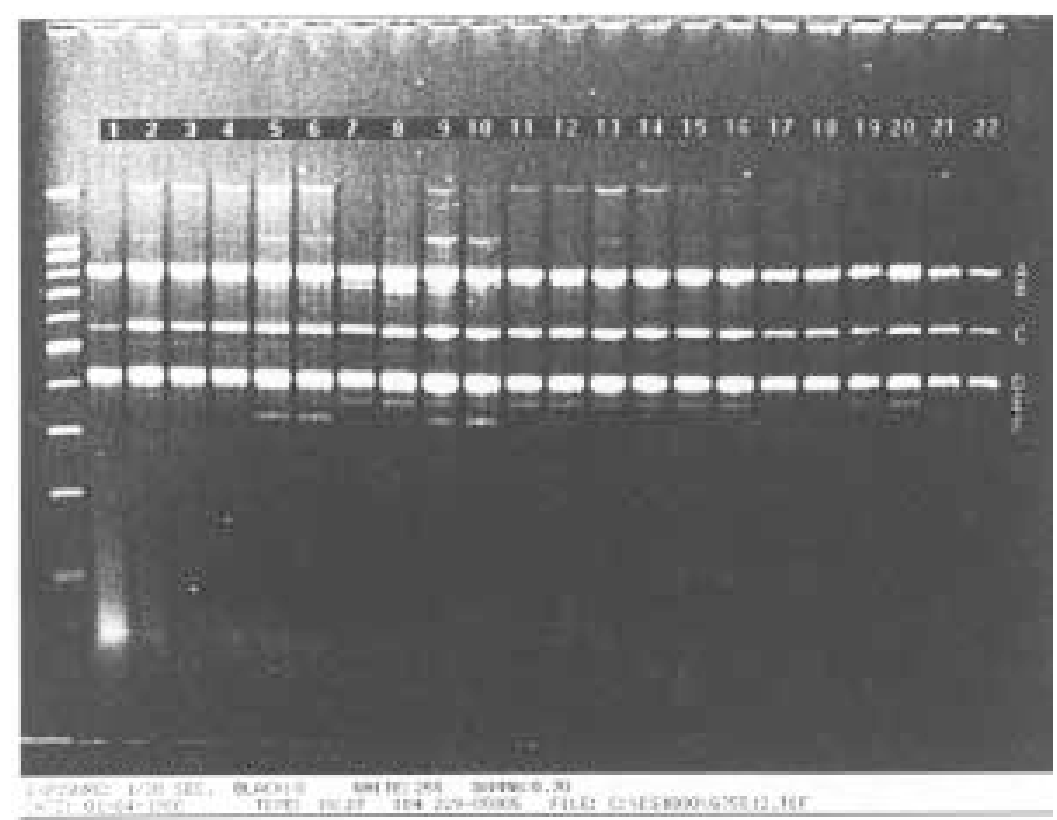


Russia and Asia, but the distinction between these groups was not entirely clean. We did not detect a pattern separating Asian and European material, although we did not include as many Asian accessions as they did.

Although China has been suggested as the origin of 'Sharkey'
(Tulecke and McGranahan, 1994), we did not recover evidence for a close relationship between 'Sharkey' and material definitely known to be of Chinese origin, as was found in analyses of RFLP (Fjellstrom et al., 1994) and RAPD (Nicese et al., 1998) data. On the other hand, a Chinese origin has also been suggested for

Table 3. ISSR profiles for the 48 Juglans regia cultivars tested. In the column beneath each primer, each letter designates a distinct banding pattern observed with that primer. Where two letters appear in one cell, it is because one of the bands generated with that primer could not be scored unequivocally in that cultivar, and had to be scored as a missing value (see text). The last two columns give, for each cultivar, the minimum number of primers necessary to provide a unique fingerprint for that cultivar and an example of such primer(s).

\begin{tabular}{|c|c|c|c|c|c|c|c|c|c|c|}
\hline \multirow[b]{2}{*}{ Cultivar } & \multicolumn{8}{|c|}{ ISSR primer no. } & \multicolumn{2}{|c|}{$\begin{array}{c}\text { Primers needed } \\
\text { for fingerprint }\end{array}$} \\
\hline & 7 & 9 & 16 & 21 & 22 & 28 & 43 & 47 & No. & Example \\
\hline 'Scharsch Franquette' & $\mathrm{A}$ & $\mathrm{A}$ & $\mathrm{A}$ & $\mathrm{A}$ & $\mathrm{A}$ & $\mathrm{A}$ & $\mathrm{A}$ & $\mathrm{A}$ & 1 & 28 \\
\hline 'Waterloo' & A & A & B & $\mathrm{B}$ & $\mathrm{B}$ & $\mathrm{B}$ & B & A & 2 & 16,21 \\
\hline 'Rouge de la Donan' & B & A & $\mathrm{C}$ & $\mathrm{C}$ & $\mathrm{B}$ & $\mathrm{C}$ & B & B & 2 & 22,28 \\
\hline 'Chinese 85-8' & $\mathrm{C}$ & A & $\mathrm{D}$ & $\mathrm{D}$ & A & $\mathrm{C}$ & $\mathrm{C}$ & $\mathrm{C}$ & 1 & 7 \\
\hline ‘Alsoszentivani' & $\mathrm{D}$ & B & B & A & A & $\mathrm{C}$ & $\mathrm{C}$ & A & 2 & 9,16 \\
\hline 'xxx Mayette’ & $\mathrm{E}$ & $\mathrm{A}$ & $\mathrm{A}$ & $\mathrm{E}$ & $\mathrm{B}$ & B & $\mathrm{D}$ & $\mathrm{D}$ & 1 & 21 \\
\hline 'Midland' & $\mathrm{E}$ & A & $\mathrm{E}$ & B & $\mathrm{C}$ & $\mathrm{D}$ & $\mathrm{C}$ & A & 2 & 21,22 \\
\hline 'Pioneer' & $\mathrm{E}$ & $\mathrm{A}$ & A & $\mathrm{C}$ & $\mathrm{C}$ & $\mathrm{B}$ & $\mathrm{C}$ & $\mathrm{C}$ & 3 & $7,16,22$ \\
\hline 'Badajoz' & A & A & A & A & $\mathrm{B}$ & B & $\mathrm{C}$ & $\mathrm{D}$ & 3 & $7,16,22$ \\
\hline 'Carmello' & $\mathrm{E}$ & A & A & $\mathrm{D}$ & $\mathrm{B}$ & B & $\mathrm{E}$ & $\mathrm{C}$ & 2 & 7,21 \\
\hline 'Lozeronne' & A & $\mathrm{A}$ & $\mathrm{F}$ & $\mathrm{F}$ & A & $\mathrm{B}$ & A & A & 2 & 21,22 \\
\hline 'Adams 10' & B & A & $\mathrm{F}$ & $\mathrm{C}$ & A & B & $\mathrm{C}$ & $\mathrm{D}$ & 2 & 7,16 \\
\hline 'Laciniata 93-5' & $\mathrm{D}$ & B & A & $\mathrm{C}$ & A & $\mathrm{B}$ & $\mathrm{E}$ & $\mathrm{D}$ & 2 & 9,16 \\
\hline 'Howard' & A & A & $\mathrm{G}$ & $\mathrm{C}$ & $\mathrm{D}$ & B & $\mathrm{D}$ & $\mathrm{C}$ & 1 & 16 \\
\hline 'Manregian' & $\mathrm{D}$ & $\mathrm{A}$ & $\mathrm{H}$ & $\mathrm{A}$ & $\mathrm{B}$ & $\mathrm{E}$ & $\mathrm{C}$ & $\mathrm{C}$ & 1 & 28 \\
\hline 'Payne' & $\mathrm{E}$ & A & I & $\mathrm{C}$ & $\mathrm{D}$ & $\mathrm{F}$ & $\mathrm{F}$ & $\mathrm{C}$ & 2 & 28,43 \\
\hline 'Sunland' & $\mathrm{E}$ & A & A & $\mathrm{C}$ & $\mathrm{D}$ & G & $\mathrm{F}$ & A & 1 & 28 \\
\hline 'Vina' & $\mathrm{E}$ & A & $\mathrm{F}$ & $\mathrm{C}$ & $\mathrm{B}$ & $\mathrm{H}$ & $\mathrm{F}$ & $\mathrm{C}$ & 2 & 22,28 \\
\hline ‘Ashley’ & $\mathrm{E}$ & A & $\mathrm{E}$ & $\mathrm{C}$ & $\mathrm{D}$ & $\mathrm{D}$ & $\mathrm{F}$ & $\mathrm{C}$ & 2 & 22,28 \\
\hline 'Serr' ' & A & $\mathrm{A}$ & $\mathrm{H}$ & $\mathrm{C}$ & $\mathrm{D}$ & I & $\mathrm{F}$ & $\mathrm{C}$ & 1 & 28 \\
\hline 'Lompoc' & $\mathrm{E}$ & A & $\mathrm{F}$ & A & A & $\mathrm{H}$ & A & $\mathrm{C}$ & 2 & 16,21 \\
\hline 'Sharkey' & B & $\mathrm{A}$ & $\mathrm{J}$ & $\mathrm{D}$ & $\mathrm{B}$ & $\mathrm{J}$ & $\mathrm{G}$ & $\mathrm{C}$ & 1 & 28 \\
\hline 'Chico' & B & A & I & $\mathrm{C}$ & $\mathrm{D}$ & B & $\mathrm{D}$ & $\mathrm{C}$ & 2 & 7,16 \\
\hline 'Tehama' & $\mathrm{E}$ & A & $\mathrm{K}$ & A & B & B & $\mathrm{H}$ & $\mathrm{C}$ & 2 & 16,21 \\
\hline 'Eureka' & A & A & $\mathrm{K}$ & A & $\mathrm{B}$ & $\mathrm{F}$ & $\mathrm{E}$ & $\mathrm{D}$ & 2 & 7,16 \\
\hline 'Gustine' & $\mathrm{E}$ & A & $\mathrm{E}$ & B & $\mathrm{D}$ & B & A & A & 2 & 16,43 \\
\hline 'Placentia' & $\mathrm{D}$ & $\mathrm{A}$ & $\mathrm{J}$ & $\mathrm{D}$ & $\mathrm{B}$ & B & A & $\mathrm{C}$ & 2 & 7,16 \\
\hline 'Westside' & B & A & $\mathrm{J}$ & $\mathrm{C}$ & B & B & A & $\mathrm{C}$ & 2 & 16,21 \\
\hline 'Sinensis \#5' & B & A & A & $\mathrm{C}$ & B & $\mathrm{K}$ & I & B & 1 & 28 \\
\hline 'Marchetti' & A & A & $\mathrm{L}$ & $\mathrm{C}$ & $\mathrm{D}$ & $\mathrm{F}$ & $\mathrm{E}$ & $\mathrm{C}$ & 1 & 16 \\
\hline 'Cisco' & A & A & A & $\mathrm{D}$ & $\mathrm{C}$ & $\mathrm{F}$ & $\mathrm{C}$ & $\mathrm{C}$ & 2 & 21,22 \\
\hline 'Chandler' & A & A & $\mathrm{C}$ & $\mathrm{C}$ & $\mathrm{D}$ & $\mathrm{L}$ & $\mathrm{D}$ & $\mathrm{C}$ & 1 & 28 \\
\hline ‘Amigo' & A & A & $\mathrm{E}$ & $\mathrm{C}$ & $\mathrm{B}$ & $\mathrm{F}$ & $\mathrm{D}$ & $\mathrm{C}$ & 2 & 7,16 \\
\hline 'Hartley' & A & $\mathrm{A}$ & A & $\mathrm{G}$ & A & $\mathrm{F}$ & $\mathrm{D}$ & $\mathrm{E}$ & 2 & 22,28 \\
\hline ‘Tulare' & A & A & $\mathrm{D}$ & $\mathrm{C}$ & $\mathrm{D}$ & $\mathrm{M}$ & $\mathrm{F}$ & A & 1 & 28 \\
\hline 'Meylan' & A & $\mathrm{A}$ & $\mathrm{A}$ & $\mathrm{G}$ & A & $\mathrm{D}$ & $\mathrm{D}$ & $\mathrm{C}$ & 2 & 21,28 \\
\hline 'Early Ehrhardt' & A & A & $\mathrm{H}$ & $\mathrm{F}$ & B & $\mathrm{D}$ & $\mathrm{D} / \mathrm{K}$ & $\mathrm{C}$ & 2 & 16,21 \\
\hline 'Conway Mayette' & $\mathrm{E}$ & A & A & A & $\mathrm{B}$ & B & $\mathrm{J}$ & A & 2 & 43,47 \\
\hline 'Pedro' & $\mathrm{E}$ & A & $\mathrm{D}$ & $\mathrm{C}$ & $\mathrm{C}$ & $\mathrm{B}$ & $\mathrm{F}$ & $\mathrm{C}$ & 2 & 7,16 \\
\hline 'Purpurea 86-11' & B & A & $\mathrm{E}$ & B & B & $\mathrm{D}$ & E & $\mathrm{F}$ & 2 & 28,43 \\
\hline 'Abbotbad' & $\mathrm{D}$ & A & $\mathrm{H}$ & A & $\mathrm{C}$ & $\mathrm{F}$ & $\mathrm{H}$ & $\mathrm{E}$ & 2 & 21,22 \\
\hline 'Trinta' & E & A & M & B & $\mathrm{D}$ & $\mathrm{N}$ & $\mathrm{E}$ & $\mathrm{F}$ & 1 & 16 \\
\hline 'Idaho' & $\mathrm{D}$ & B & $\mathrm{E}$ & A & A & B & $\mathrm{J}$ & $\mathrm{C}$ & 2 & 9,16 \\
\hline 'Poe' & $\mathrm{E}$ & A & A & G & A & B & A & $\mathrm{C}$ & 2 & 7,21 \\
\hline 'Weeper' & $\mathrm{D}$ & A & A & $\mathrm{H}$ & A & $\mathrm{D}$ & $\mathrm{H}$ & $\mathrm{C}$ & 1 & 21 \\
\hline 'Concha' & B & A & A & $\mathrm{C}$ & B & $\mathrm{D}$ & $\mathrm{J}$ & $\mathrm{C}$ & 2 & 28,43 \\
\hline 'Cascade' & $\mathrm{E}$ & A & B & $\mathrm{C}$ & A & B & F & $\mathrm{D}$ & 2 & 16,21 \\
\hline 'Franquette' & A & A & $\mathrm{N}$ & I & A & $\mathrm{N}$ & A & $\mathrm{D}$ & 1 & 21 \\
\hline
\end{tabular}




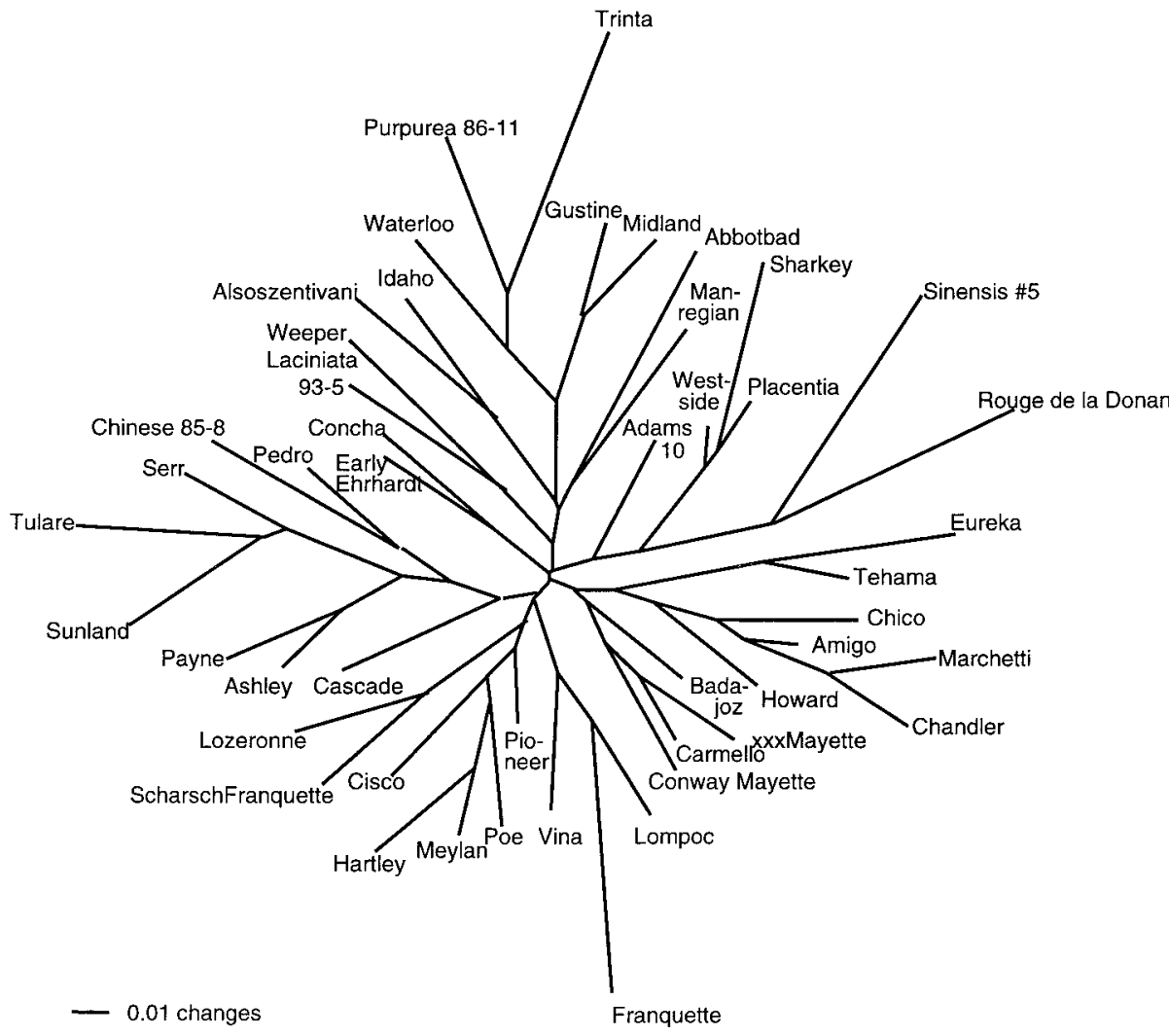

Fig. 3. Dendrogram of Juglans regia cultivars obtained by neighbor-joining analysis using genetic distances based on ISSR data.

'Placentia' (Tulecke and McGranahan, 1994), which, along with 'Westside' (whose lateral fruit-bearing may indicate a relationship to Chinese materials) groups with 'Sharkey' in our analysis (Fig. 3).

As discussed above, we assume that the shortness of the internal branches in Fig. 3 and the lack of correspondence between the topology of our dendrogram and much of the geographic and pedigree data for the cultivars result, in part, from the complex history of walnut breeding. In addition, however, several methodological factors may limit the degree to which molecular markers in general, and ISSR data in particular, are informative about relationships among cultivars (Davierwala et al., 2000; Goulão et al., 2001; Gulsen and Roose, 2001).

Poor correlations between dendrograms based on molecular marker data and known pedigrees, as well as between dendrograms based on different types of molecular markers, have been observed in studies of several other crops, including rice (Oryza sativa L.; Davierwala et al., 2000) and lemons [Citrus limon (L.) Burm. f.] (Gulsen and Roose, 2001), and various reasons have been proposed to explain this lack of correspondence. While heterogeneity of ancestral cultivars and inaccurate pedigree data may be important factors in some crops (Davierwala et al., 2000), they are probably not significant for this study, since walnuts are clonally propagated and good records have been kept concerning the origins of most of the cultivars we examined. Incomplete genome coverage by the markers examined is a potential problem (Bohn et al., 1999), especially when just one marker system is used (Davierwala et al., 2000). Increasing the number of primers used may help, but, unless the genomic locations of those primers are mapped, there is no way to assess the thoroughness of genome sampling.
A problem shared by several methods, including ISSR markers, is that bands of the same size in different accessions may not be homologous, especially when more distantly related materials are compared. This is probably not a significant issue for studies of cultivated germplasm of a single species, but the possibility that some bands represent artifacts rather than true genetic differences must also be considered (Gulsen and Roose, 2001). Another potential problem with using ISSR markers for inferring genetic relationships is the presence of nonparental bands (i.e., bands that occur in the progeny of a cross but not in either of its parents), which may result from competition during PCR amplification (Goulão et al., 2001; Halldén et al., 1996). In our data set, there were four instances of nonparental bands. This represents $0.27 \%$ of the total of 1488 data points (considering polymorphic bands only) and $4.1 \%$ of the total of 97 opportunities for detecting such bands (i.e., cases where we had data from a cultivar and both of its parents and where both parents were lacking a band found in some cultivars analyzed). Goulão et al. (2001), in their ISSR analysis of plum cultivars, found that nonparental bands represented $3 \%$ of total bands scored. The fact that nonparental bands can occur in ISSR analysis means that the method may sometimes be misleading regarding parentage of individuals; on the other hand, the low frequency with which this occurs suggests that it may not be a significant problem, especially if large numbers of primers are analyzed.

A more significant limitation is the fact that each ISSR marker has only two allelic forms (presence or absence of a band); in this respect, SSR markers, with potentially higher allelic diversity, might be superior for tracking cultivar relationships (Métais et al., 2000). Finally, and perhaps most importantly, ISSR markers, like RAPD and AFLP markers, are dominant markers, precluding the possibility of detecting heterozygosity. This probably accounts, in part, for the lack of complete correspondence between our dendrogram and that of Nicese et al. (1998) and the known pedigrees for these cultivars.

\section{Conclusions}

ISSR data yielded unique fingerprints for all walnut cultivars tested; the method is therefore useful for cultivar identification. ISSR data can also provide some information on genetic relationships among cultivars, but their utility in this regard may be limited. In conjunction with other data, however, ISSR markers can help provide information on the origins of walnut germplasm.

The ISSR method has some disadvantages, discussed above, but it has the advantage of being a relatively inexpensive technique to optimize and run. A project is currently underway at the U.S. Department of Agriculture National Clonal Germplasm Repository, Davis, Calif., to develop SSR, or microsatellite, markers for walnut. As noted above, microsatellites are generally considered superior to ISSR markers for a number of reasons, including higher reproducibility and codominant inheritance. Once the considerable cost of developing SSR markers has been 
expended, the cost of running them is equivalent to methods such as ISSR and RAPD markers. We therefore expect that microsatellite markers will replace other technologies for identifying and studying genetic relationships among J. regia cultivars within a few years.

\section{Literature Cited}

Arulsekar, S., G.H. McGranahan, and D.E. Parfitt. 1986. Inheritance of phosphoglucomutase and esterase isozymes in Persian walnut. J. Hered. 77:220-221.

Beede, R.H. and J.K. Hasey 1998. History of the walnut in California, p. 8-15. In: D.E. Ramos (ed.). Walnut production manual. Univ. of Calif., Div. of Agr. Natural Resources, Oakland.

Bohn, M., H.F. Utz, and A.E. Melchinger. 1999. Genetic similarities among winter wheat cultivars determined on the basis of RFLPs, AFLPs, and SSRs and their use for predicting progeny variance. Crop Sci. 39:228-237.

Davierwala, A.P., K.V. Chowdari, S. Kumar, A.P.K. Reddy, P.K. Ranjekar, and V.S.Gupta. 2000. Use of three different marker systems to estimate genetic diversity of Indian elite rice varieties. Genetica 108:269-284.

Doyle, J.J. and J.L. Doyle. 1987. A rapid DNA isolation procedure for small quantities of fresh leaf tissue. Phytochem. Bul. 19:11-15.

Fang, D.Q., R.R. Krueger, and M.L. Roose. 1998. Phylogenetic relationships among selected Citrus germplasm accessions revealed by intersimple sequence repeat (ISSR) markers. J. Amer. Soc. Hort. Sci. 123:612-617.

Fang, D.Q., M.L. Roose, R.R. Krueger, and C.T. Federici. 1997. Fingerprinting trifoliate orange germplasm accessions with isozymes, RFLPs, and inter-simple sequence repeat markers. Theor. Appl. Genet. 95:211219.

Fjellstrom, R.G., D.E. Parfitt, and G.H. McGranahan, 1994. Genetic relationships and characterization of Persian walnut (Juglans regia L.) cultivars using restriction fragment length polymorphisms (RFLPs). J. Amer. Soc. Hort. Sci. 119:833-839.

Forde, H.I. and G.H. McGranahan. 1996. Walnuts, p. 241-273. In: J. Janick and J.N. Moore (eds.). Fruit breeding. vol. III. Nuts. Wiley, New York.

Goulão, L., L. Monte-Corvo, and C.M. Oliveira. 2001. Phenetic characterization of plum cultivars by high multiplex ratio markers: Amplified fragment length polymorphisms and inter-simple sequence repeats. J. Amer. Soc. Hort. Sci. 126:72-77.

Gulsen, O. and M.L. Roose. 2001. Lemons: Diversity and relationships with selected Citrus genotypes as measured with nuclear genome markers. J. Amer. Soc. Hort. Sci. 126:309-317.

Halldén, C.M., M. Hansen, N.O. Nilsson, A. Hjerdin, and T. Sall. 1996. Competition as a source of errors in RAPD analysis. Theor. Appl. Genet. 93:1185-1192.

Lin, H. and M.A. Walker. 1998. Identifying grape rootstocks with simple sequence repeat (SSR) DNA markers. Amer. J. Enol. Viticult. 49:403407.

Métais, I., C. Aubry, B. Hamon, R. Jalouzot, and D. Peltier. 2000. Description and analysis of genetic diversity between commercial bean lines (Phaseolus vulgaris L.). Theor. Appl. Genet. 101:1207-1214.

Moreno, S., J.P. Martín, and J.M. Ortiz. 1998. Inter-simple sequence repeats PCR for characterization of closely related grapevine germplasm. Euphytica 101:117-125.

Nagaoka, T. and Y. Ogihara. 1997. Applicability of inter-simple sequence repeat polymorphisms in wheat for use as DNA markers in comparison to RFLP and RAPD markers. Theor. Appl. Genet. 94:597602 .

Nicese, F.P., J.I. Hormaza, and G.H. McGranahan. 1998. Molecular characterization and genetic relatedness among walnut (Juglans regia L.) genotypes based on RAPD markers. Euphytica 101:199-206.

Simon, C. and D. Potter. 2001. Development of highly reliable molecular markers for walnut, p. 64-65. In: Walnut research reports 2000. Walnut Mkt. Board, Sacramento, Calif.

Solar, A., J. Smole, and F. Stampar. 1993. Identification of walnut cultivars by pollen isozymes. Acta Hort. 311:95-99.

Solar, A., J. Smole, and F. Stampar. 1994. Characterization of isozyme variation in walnut (Juglans rsegia L.) Euphytica 77:105-112.

Swofford, D. 2001. PAUP*. Phylogenetic analysis using parsimony (* and other methods). version 4. Sinauer Assoc., Sunderland, Mass.

Tulecke, W. and G.H. McGranahan. 1994. The walnut germplasm collection at the University of California, Davis: A description of the collection and a history of the breeding program of Eugene F. Serr and H.I. Forde. Rpt. 13. Univ. Calif. Genetic Resources Conservation Program, Davis.

Zietkiewicz, E., A. Rafalski, and D. Labuda. 1994. Genome fingerprinting by simple sequence repeat (SSR)-anchored polymerase chain reaction amplification. Genomics 20:176-183. 